\title{
Are Monetarists an Endangered Species?
}

\author{
DALLAS S. BATTEN and COURTENAY C. STONE
}

M sharp attack over the past few years. Recent critics have detailed "The Trouble With Monetarism," argued that the choice is between Monetarism or Prosperity and even recoiled in horror from the Scourge of Monetarism. ${ }^{1}$ Various accounts of the failure of monetarism in Argentina, Canada, Chile and Great Britain have received widespread attention. ${ }^{2}$ Moreover, monetarism in the United States has been described as a "Cod that failed," and there have been numerous reports that monetarism is now virtually dead. $^{3}$

\footnotetext{
"Alan Reynolds, "The Trouble with Monetarism," Policy Review (Summer 1982), pp 19-42; Bryan Could, John Mills and Shaun Stewart, Monetarism Or Prosperity (Macmillan Press Ltd., 1981); and Nicholaus Kaldor, The Scourge of Monetarism (Oxford University Press, 1982).

${ }^{2}$ See, for example, "Monetarism loses face north of the border," Economic Diary, Business Week (December 20, 1982), p. 12; John Kirbyshire, "Monetarism Remains Economic Scapegoat," New York Journal of Commerce, November 4. 1982; "In Britain, monetarism took a heavier toll," Business Week (April 4, 1983), pp. 66-67; Jeremy Morgan, "Argentina Abandons Monetarism," New York Journal of Commerce, June 19, 1982; and Everett $G$. Martin, "Milton Friedman's Proteges in Chte See Influence Declining Because of Recession," The Wall Street Journal, fuly $27,1982$. Even discussions of monetarism can produce conflicts; see "Friedman's Views Ignite Political Debate in Peru," Washington Post, Novenber 22, 1981 .

${ }^{3}$ For the most recent citation that monetarism has failed in the United States, see "The Failure of Monetarism," Business Week (April 4, 1983), pp. 64-67. For earlicr criticisms, see Andrew $F$. Brimmer, "A Returra to Monetarism: the Dangers," American Banker, February 3, 1983; Stwart E. Eizenstat, "Volcker's Monetarist Policy: Painful, Costly," The New York Times, October 18, 1982 William D. Nordhaus, "Destroying the Economy to Save It," The New York Times, December 26 , 1982, Peter Field, "The Death of Reaganomies," Euromoney (September 1982), pp. 95107; and Irving Kristol, "The Big Question: Is 'Reaganomics' Working?" The Wall Street Journal, October 14, 1982. Apparently the only nations where monetarism currently is practiced unchallenged are the People's Republic of China and the Soviet Union; see Leo Goodstadt, "The Great Chinese Economic Retreat," Euromoney (April 1981), pp. 73-77; Milton Friedman, "Marx and Money, Newsweek (October 27, 1980), p. 95; and Milton Friednan, "Defining Monetarism," Neusweek (July 12, 1982), p. 64.
}

The alleged death of monetarism could not have come at a more inappropriate time. Milton Friedman and Anna Schwartz have just published a massive volume entitled Monetary Trends in the United States and the United Kingdom: Their Relation to Income, Prices and Interest Rates $1867-1975 .{ }^{4}$ In that text, they present extensive and detailed evidence that supports the basic monetarist propositions regarding the impact of money on the economy. ${ }^{5}$ It would be both ironic and puzzling if, at the very time that their findings are published, we were to discover that these fundamental relationships suddenly have broken down.

Yet, this claim is precisely the one that critics of monetarism have made. They charge that recent finan" cial innovations and the expanding use of previous financial innovations have so distorted the measure and meaning of money that monetarism, no matter how well supported by historical studies, is no longer valid. Since this claim has been made before and found, in each instance, to be groundless, it should be met with considerable skepticism. ${ }^{7}$

\footnotetext{
Milton Friedman and Amna J. Schwartz, Monetary Trends in the United States and the United Kingdom: Their Relation to Income, Prices and Interest Rates, $1867-1975$ (University of Chicago Press, for the National Bureat of Economic Research, 1982).

${ }^{5}$ For detailed reviews of the just published Friedman and Schwartz volume, see David Laidler, "Friedman and Schwartz on Monetary Trends: A Review Artide," Journal of International Money and Finance (December 1982), pp. 293-305, Thomas Mayer, "Monetary Trends in the Uuited States and the United Kingdom: A Review Article," Joumal of Economic Literature (December 1982), pp. 1528-39; Charles A. E. Goodhart "Monetary Trends in the United States and the United Kingrom: A British Review," Journal of Economic Literature (December 1982), pp. 1540-51, and Robert $\mathrm{E}$. Hall, "Monetary Trends in the United States and the United Kingdom: A Review from the Perspective of New Developments in Nonetary Economics,"Journal of Economic Literature (December 1982), pp. 1552-56.

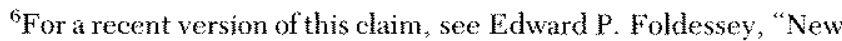
Bank Accounts May Force Fed to End Experiment in Monetarism," The Wall Street Journal, December 28, 1982.

"Fot an assessment of the "monetarism has failed" dain circia 1972 see Daryl R. Francis, "Has Monekarism Failed? - The Record Examined," this Review (March 1972), pp. $32-38$.
} 
This article attempts to assess whether current rumors of the demise of monetarism are grealy exaggerated.

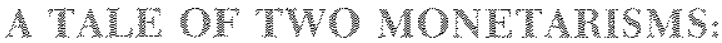

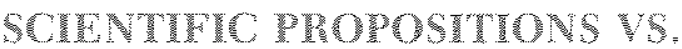 NORMATIVE PRESCRPIONON}

Perhaps the most significant obstacle to understanding many of the current arguments, both for and against monetarism, is that the term typically is bandied about with little or no specific reference to its intended meaning. This is a problem because monetarism can refer to two very different kinds of statements. Monetarism can refer to specific, testable, scientific propositions; it also can be used to indicate a set of policy suggestions or alternatives to achieve desired economic goals. ${ }^{8}$ In the scientific sense, we can assess easily whether monetarism has failed. In the normative or policy sense, however, it may be impossible to agree whether monetarist policies have even been attempted, let alone have failed.

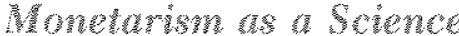

Looked at in a scientific sense, monetarism is the label attached to a common set of theoretical and empirical propositions regarding the significant and stable relationship between the money stock and other important economic variables. There is a methodology, common to all sciences, that is used to assess the logical validity and empirical support for competing theories. Scientific theories never die by themselves; they are abandoned only when a better theory comes along. If monetarism, in the scientific sense of the word, has failed, it must have succumbed to an alternative non-monetarist explanation.

It is clear that, within the scientific framework of the rise and demise of theories, monetarism has not been superseded by newer or superior theories of inflation or real output or spending growth. ${ }^{9}$ Instead, critics charge that the behavioral relationships that worked well in the past have shifted and that the previously stable relationships underlying the monetarist view have now become unstable. If this has occurred, then the propositions labeled monetarism would become less useful. In the extreme, they would even be re-

\footnotetext{
"This distinction is discussed briefly in Milton Friedman's "Defining Monetarism,"

The presumed failure of all economic theories has been noted recently by John Greenwald, "Where Have All the Answets Gone? Time (January 17, 1983), pp. 36-37.
}

placed by some previously less useful, non-monetarist theory. This issue is analyzed in the latter part of this article.

\section{Monelarism as wh tonomic Polaty}

In addition to its scientific meaning, however, monetarism also can be used in a normative or policy sense. As such, it serves as a label for a set of economic policy prescriptions intended to achieve certain economic goals. Of course, such policy prescriptions presuppose that monetarism, in the scientific sense, is valid and that policymakers can exert some control over money growth.

There are several fundamental problems with attempting to assess the success or failure of normative monetarism. First, there may be no common agreement on whether a monetarist policy has been followed; consequently, it will be virtually impossible to demonstrate that it has failed. To illustrate this problem, consider the data shown in table 1. A number of countries have announced a variety of monetary aggregate targets over the past three years; six of these are represented in the table. Because these countries have adopted and publicly announced such targets, numerous commentators have labeled their policies as monetarist. Because these targets generally were not achieved and because economic conditions in these countries over the past three years were generally poor, it has been charged that monetarism has failed.

At the same time, other analysts have used the same data to support the opposite conclusion. Because the announced targets were not achieved, they argue, the actual behavior of the monetary authorities was clearly non-monetarist. Further, the resultant adverse economic conditions are used to demonstrate why monetarist policies should have been followed.

A prime example of the problem associated with determining whether a specific policy is monetarist is the widespread disagreement over whether the Federal Reserve has been following a "monetarist" policy since October $1979 .{ }^{10}$ When a group of policymakers, economists and financial analysts were asked this question recently by the Joint Economic Committee of the U.S. Congress, their answers ranged from the strongly affirmative to the strongly negative to the inscrutably

\footnotetext{
${ }^{10}$ On October 6, 1979, the Federal Reserve announced that it had changed its operating procedures to achieve enhanced control over money. This change in policy implementation was relaxed in October 1982.
} 


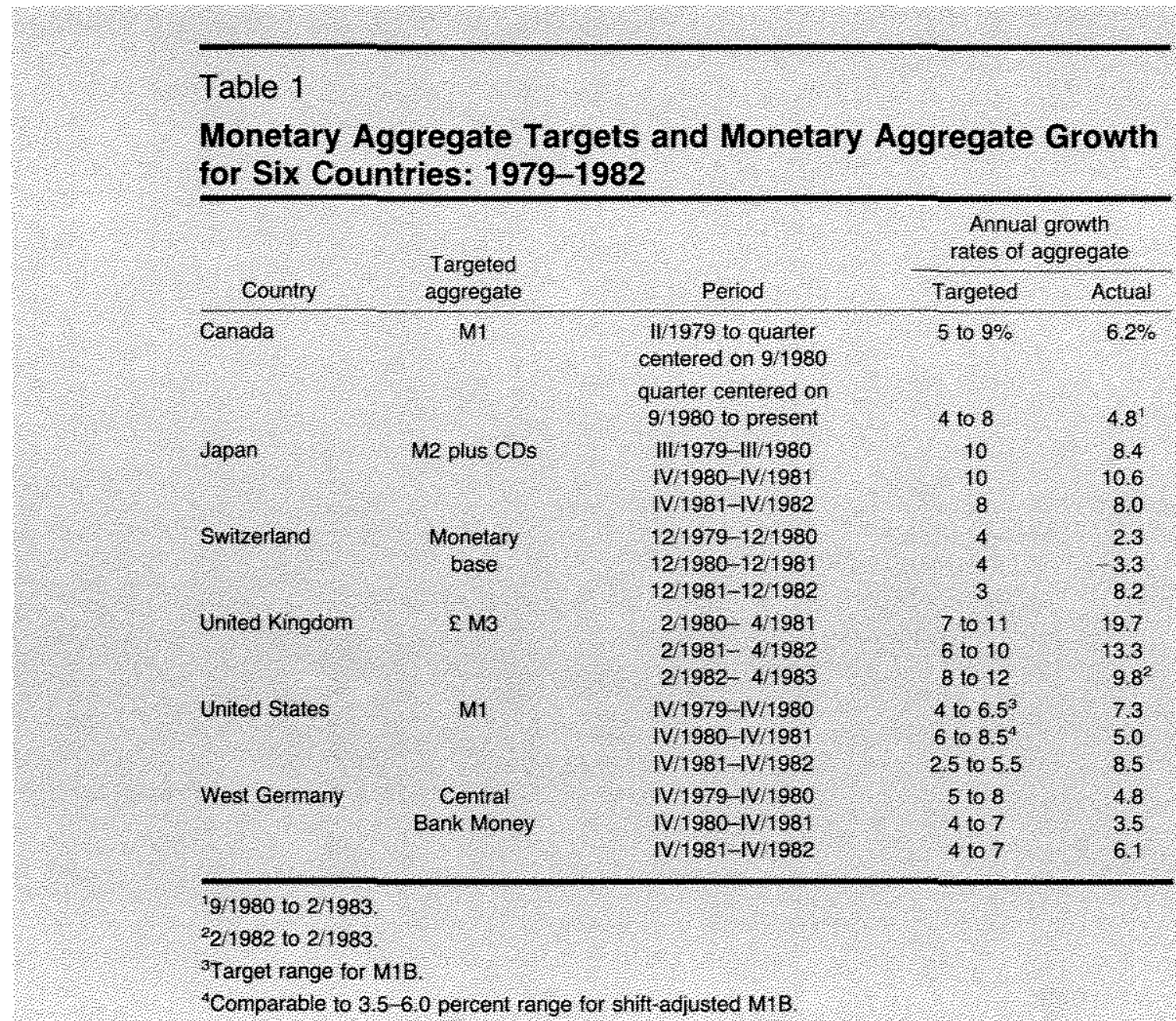

cryptic. ${ }^{\text {II }}$ The basic problem is simply that reasonable people can differ both on their interpretation of whether a specific policy is monetarist and whether it is being carried out in a monetarist fashion.

A different problem with assessments of policy failures is that policymakers and the general public appear to shift back and forth among a variety of goals; further, they often fail to agree among themselves on the likely outcome of policy actions. ${ }^{12}$ Flip-flopping between policy goals can lead to erratic policy actions

\footnotetext{
"Monetarism and the Federal Reserve's Conduct of Monetary Policy. Compendium of Views Prepared for the Use of the Subcommittee on Monetary and Fiscal Policy of the Joint Economic Committee, Congress of the United States, 97 Cong. 2 Sess. (U.S. Goveriment Printing Office, December 30, 1982).

"For the apparent "shiftiness" of monetary policy goals, see Richard Froyen, "A Test of the Endogeneity of Monetary Policy," Journal of Econometrics (July 1974), pp. 175-88; Richard $K$. Abrams, Richard Froven and Roger N. Waud, "Monetary Policy Reaction Functions, Consistent Expectations, and the Burns Era, Journal of Money, Credit and Banking (February 1980), pp. 30-42; John H. Wood, "A Model of Federal Reserve Behavior, in George Horwich, ed., Monetary Process and Policy: A Sympo-
}

that are unlikely to fit neatly into any category monetarist or non-monetarist. Disagreement over the likely outcomes of policy actions will lead typically to different assessments by policymakers and others about the "success" of policy actions. To some, policy will have succeeded; to others, it will have failed.

Debates over whether monetarist monetary policies have been tried, or whether they have failed, or even whether they were the appropriate monetarist policies, are unlikely to be resolved. In the normative sense, a discussion of whether monetarism has failed is both inconclusive and, probably, nonsensical as long as there is such widespread disagreement. These discussions only serve to draw attention from the crucial issue that can be resolved - whether monetarism, in the

sium (Richard D. Irwh, 1967) pp. 135-66; and Thomas M. Havrilesky, Rohert H. Snapp and Robert L. Schwertzer, "Test of the Federal Reserve"s Reaction to the State of the Economy, "Social Science Quarterly (March 1975), pp. 743-52. For a statement of the failure of monetary policymakers to ayree on what the actual outcome of policy is likely to be, see John M. Berry, "Fed to Resist Call on Hill for Its Economic Goals," Washington Post, April 5, 1983. 
scientific sense, has failed. If scientific monetarism has failed, then discussions over normative monetarist issues are meaningless; there can be no useful monetarist policies if the relationships between money growth and other important economic variables are unstable or nonexistent. On the other hand, if scientific monetarism has not failed, discussions over whether some policy can be labeled as monetarist are mere bagatelles; what matters is not the label attached to the policy, but the actual pattern of money growth that the policy produces. The crucial issue that must be addressed is the success or failure of scientific monetarism.

\section{ROUR WRULWOWN SCWNTW MONETARST POPOOSTTONS: WAVE Then}

There are a large number of economic propositions that have come to be associated with monetarism, or at least with individuals who have been labeled monetarists. ${ }^{133}$ We do not intend to investigate all such propositions. Instead, we focus on what we consider to be four key monetarist propositions. The first three

\footnotetext{
${ }^{23}$ For statements, suggestions and, in some cases, extensive lists of what monetarism means, see Karl Brunner, "The Role of Money and Monetary Policy," this Review (July 1968), pp. 9-24; Darryl R. Francis, "An Approach to Monetary and Fiscal Management," this Review (November 1968), pp. 6-10; Allan Meltzer, "Controlling Money," this Review (May 1969), pp. 16-24, Karl Brmmer, "The Monetarist View of Kevnesian Ideas," Lloyds Bank Revtew (October 1971), pp. 35-49; A. Robert Nobay and Harry G. Johnson, "Monetarism: A Historic-Theoretic Perspective," Journal of Economic Literature (June 1977), pp. 470-85; Jerome L. Stein, ed., Monetarism (North-Holland Publishing Co., 1976); Thomas Mayer, The Structure of Monetarism (W. W. Norton \& Company, Inc., 1978), especially p. 2; Brian Morgan, Monetarists and Ketmesians: Their Contribution to Monetary Theory (Halsted Press, 1978), especially pp, 89-91; Howard R. Vane and John L. Thompson, Monetarism: Theory, Evidence and Policy (Halsted Press, 1979), especially pp. 3-16; Doutalas D. Purvis, "Monetarism: A Review," Canadian Journal of Economics (February 1980), pp. 96-121; David Laidler, "Monetarism: An Interpretation and an Assessment," The Economic Journal (March 1981), pp. 1-28; and John Burton, "The Varieties of Monetarism and Their Policy Implications," The Three Banks Review (Jume 1982), pp. 14-31. Needless to say, these are only a few of the huge number of articles and books on this issue. Moreover, there are a host of alleged kinds of monetatists and monetarism. John Burton provides the followng listing in "The Varieties of Monetarism": Marxist, Friedmanite, rational expectations, global, fiscal, Austrian and Thatcherite. Herbett Stein, in "Monetarism Under Fire," AEI Economist (September 1981), pp. 1-8, distinguishes three eategories of monetarists: hall-way, true-blue and gold-standard. Robert $D$. Anerbach in Monefarism and the Federal Reserves Conduct of Monetary Policy, pp. 39-45, lists the following kinds of monetarists: exaggerated or nave, cameo, asymmetric, creeping asymmetric, commodity target, distant target, changing target, multiple target, conventional, central banks, one-issue-at-at-time and interest rate. Finally, there are numerous different kinds of pejorative monetarism that are mentioned frequently; among oar
}

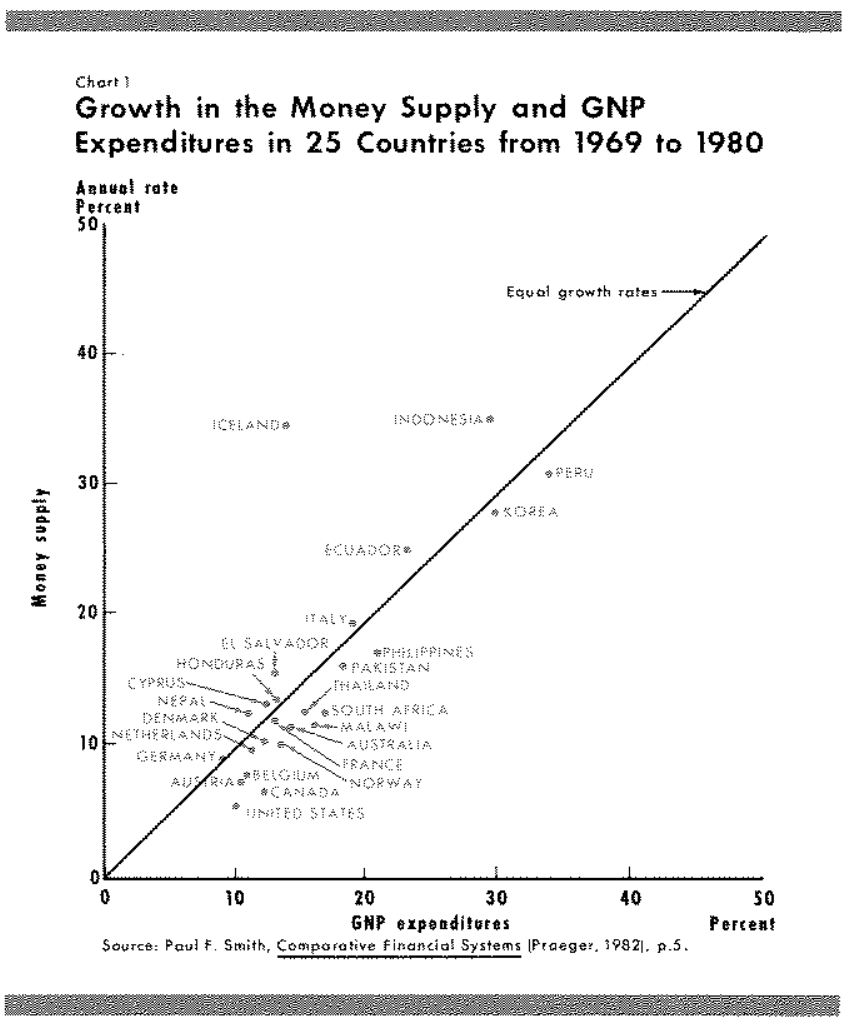

propositions concern "what money does"; they represent the relationship between money growth and the growth of aggregate spending, prices and real output. The fourth proposition focuses on the controllability of money growth. The first three propositions demonstrate why money matters; the fourth proposition investigates whether monetary policy matters.

Proposition 1: There is a close and stable relationship between the growth of money and the growth of total spending. This relationship can be investigated in a variety of ways. One simple way is to compare the growth of M1, the narrow monetary aggregate consisting of currency and checkable deposits, to the growth of aggregate spending, measured by Gross National Product (GNP) or Gross Domestic Product (GDP). This is done in chart 1 for a large number of countries for the 1969 to 1980 period. It is clear from the chart that, in general, there is a very close relationship between growth in money and growth in total spending; the vast majority of the countries are clustered close to the 45-degree line that denotes equal growth rates for both money and spending over the period.

favorites are: miscreant, fintywed, macho, kneejerk, simple, simplistic and mechanical. Given the above varieties of both monetarism and monetarists, it is crucial, in any evaluation of monetarism, that the term be carefully defined and consistently used. 
A more analytical method of assessing the relationship between growth in MI and GNP for the United States involves the use of the St. Louis equation, which was developed specifically to investigate the impact of monetary and fiscal actions on GNP.

The St. Louis equation typically is written as:

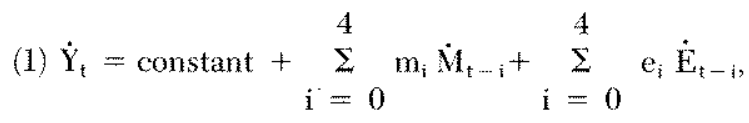

where $\dot{Y}, \dot{M}$ and $\dot{\mathrm{E}}$ are the annualized quarterly growth rates of GNP, Ml and high-employment government expenditures, respectively, $m_{i}$ and $e_{i}$ represent the impact of current and lagged values of $\dot{\mathrm{M}}$ and $\dot{\mathrm{E}}$, respectively, the constant term represents the impact of other influences on GNP growth, and $\mathrm{i}=0, \ldots, 4$ shows that the equation investigates the extent to which GNP growth in quarter $t$ is affected by the current and past four quarters' growth in $\mathbf{M}$ and $\mathbf{E}$.

Table 2 shows the results of estimating this equation over the period from II/1960 to IV/1982. There are three key aspects to these results. First, as the $\overline{\mathbf{R}}^{2}$ shows, the estimated equation accounts for a sizable proportion of the actual fluctuations in GNP growth; in this instance, about 30 percent of the variation in $Y$ is explained by the variables on the right-hand side of the equation. Second, the explanatory power of the equation is derived solely from the monetary variables; only the estimated coefficients on $\dot{\mathrm{M}}$ are statistically different from zero. Third, the sum of the coefficients on $\dot{M}$ is not significantly different from one; this indicates that, other things unchanged, any given change in the growth of $\mathrm{Ml}$ will produce the same change in the growth of GNP within five quarters.

Another way of looking at this relationship can be seen in chart 2 , which contains the year-to-year growth rates of nominal GNP and MI for the United States. Clearly, changes in the growth of GNP from one year to the next are positively associated with changes in the growth of M1.

If monetarism has failed due to recent financial innovations, then the relationships estimated in table 2 and shown in chart 2 should have eroded substantially since late $1979 .{ }^{14}$ This purported erosion is not apparent in chart 2: the link between money growth and economic activity since III/1979 seems no different

\footnotetext{
${ }^{14}$ Since it is never possible to identify a single beginning point for a continuous process like financial innovation, the date of the Fed's change in operating procedures (October 1979) is used as the break point in this, and all subsequent, analysis.
}

\section{Table 2}

\section{Estimation of St. Louis Equation: II/1960 to IV/1982}

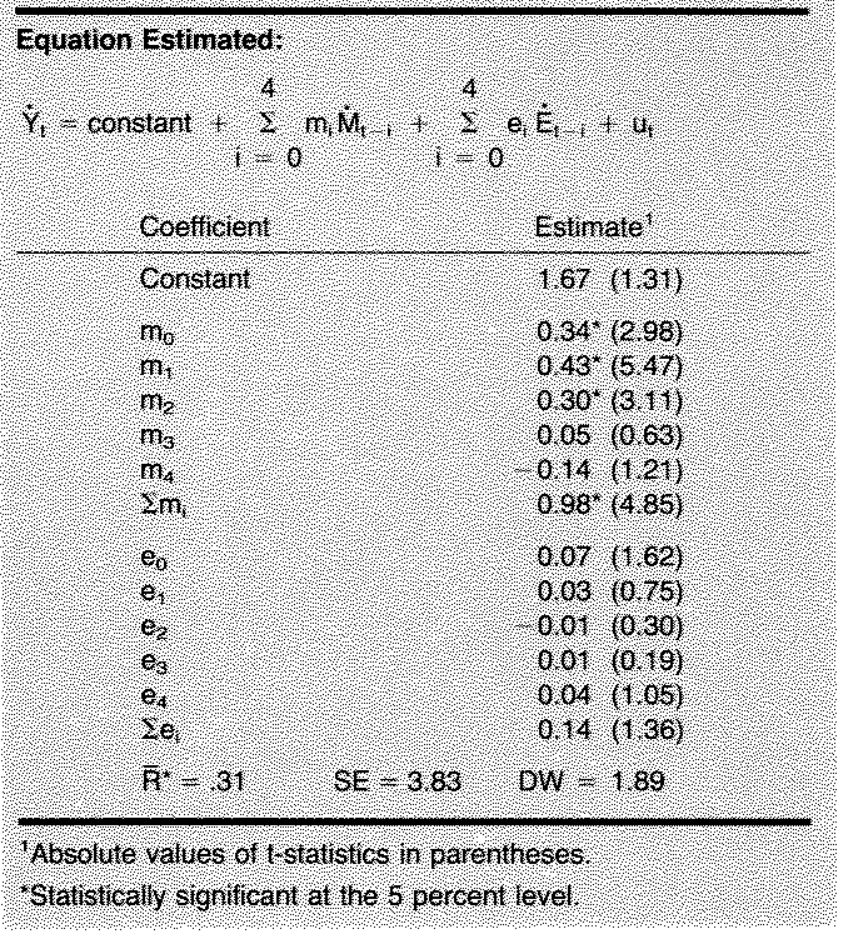

from that which existed during the previous two decades.

Of course, visual evidence is never conclusive; appearances always can be deceiving. What is significant is that there is no statistical support that the relationship between money and spending in the St. Louis equation has broken down in recent years. When the parameters of the St. Louis equation were tested for their structural stability, the hypothesis that the structure had "slipped" in the later period was rejected. ${ }^{15}$ Thus, there does not appear to have been a

\footnotetext{
${ }^{15}$ The stability of the coefficients in equation $I$ is examined by estimating

$$
+\sum_{i=0}^{4} e_{i j} \dot{L}_{t-i}+\sum_{i=0}^{4} e_{2 j} \mathrm{DE} \dot{E}_{t \cdots i}+e_{t},
$$

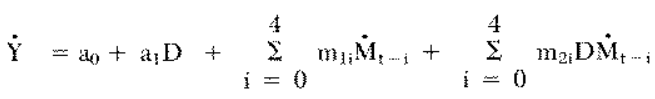

where D, a dimny variable, equals I from $1 / 1960$ to $111 / 1979$ and 0 otherwise. The stability test for the coefficients on MI growth is conducted by testing the jomt hypothesis that all of the estimates of $m_{2 i}$ are simulameously equal to zero. The calculated $F_{\text {-statistic }}$ for this test is 2.01 ; the critical $F$-value is 2.72 for the 5 percent significance level. Consequently, the hypothess that the coefficients on MI growth have changed since IIV/1979 can be rejected at the 5 percent significance level.
} 
Chart 2

\section{Growth Rates of Ml and Nominal GNPL}

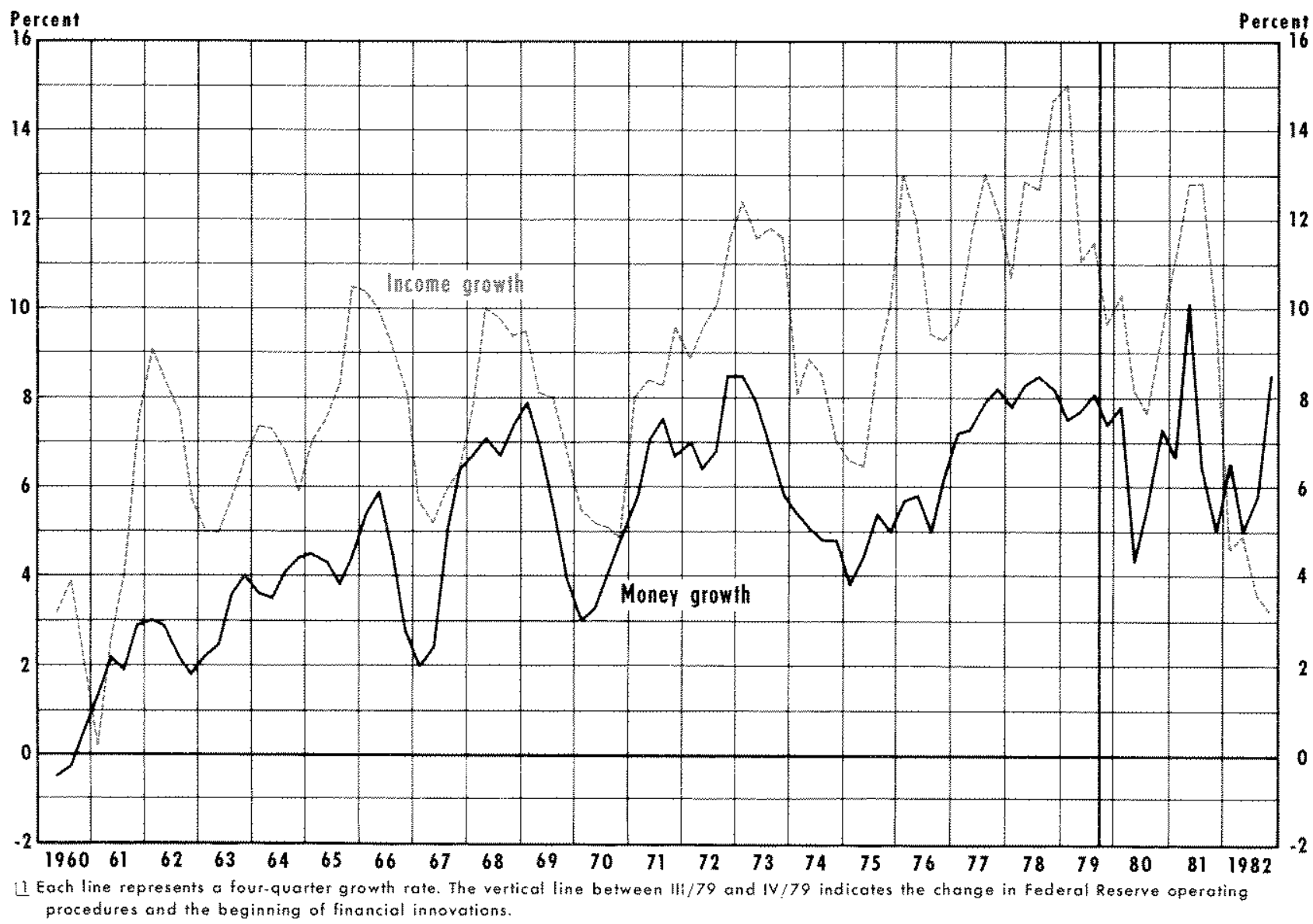

sudden failure of monetarism in the $1980 \mathrm{~s}$, at least as judged by the relationship between money growth and the growth of total spending. 16

The second and third propositions are concemed with how changes in money growth affect the two fundamental components of nominal $\mathrm{GNP}$ growth real GNP growth and price growth (inflation).

Proposition 2: Inflation is primarily a monetary phenomenon. This proposition states that there is a close positive relationship between the trend growth in money and the growth in prices over long periods of time. One example of the universality of this relationship is shown in table 3 for a variety of countries

\footnotetext{
${ }^{16}$ For further evidence that innovations have had no significant impact on M1, see John A. Tatom, "Recent Financial Innovations: Have "They Distorted the Meaning of Ml?" this Revieu (April 1982), pp. 23-35 and "Money Market Deposit Accounts, SuperNows and Monetary Pollcy," this Review (March 1983), pp. $5-16$.
}

Table 3

Money Growth and Inflation Across Countries: $1973-1980$

\begin{tabular}{|c|c|c|}
\hline \multirow[b]{2}{*}{ County } & \multicolumn{2}{|c|}{ Average annual rates of } \\
\hline & Mt growh & Sntwon \\
\hline taly & $18,3 \%$ & $776 \%$ \\
\hline Unied Kingdon & 130 & 164 \\
\hline France & 109 & 106 \\
\hline Japan & 94 & 70 \\
\hline canada & 89 & 100 \\
\hline Gernany & 87 & 47 \\
\hline Netherlands: & 84 & 78 \\
\hline Belgun & 66 & 74 \\
\hline Oniveo states & 64 & 77 \\
\hline Switenland & 38 & 36 \\
\hline
\end{tabular}

Measured oy GNP deftator. 


\section{M1 Growth and Inflation}

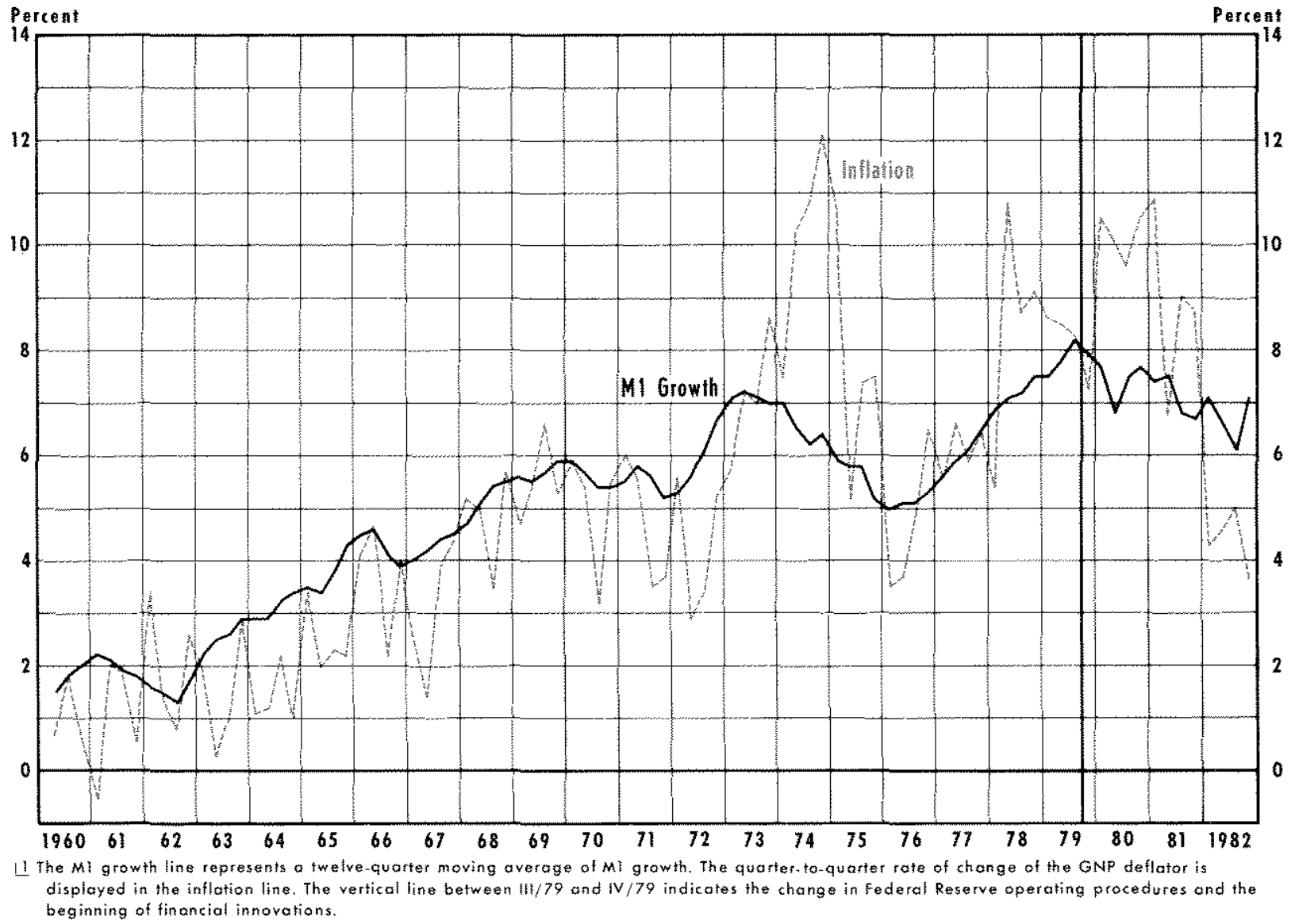

over the period from 1973 to 1980 . With few exceptions, those countries with the greater $\mathrm{Ml}$ growth also had the higher rates of inflation.

Another way to assess the relationship between price changes and money growth is to separate the monetary and non-monetary influences on prices to determine their relative importance at various points in time. Since it is the trend growth in money that influences prices, the monetary influence on the rate of inflation in any period is the growth in money over some fairly long past period. ${ }^{7}$ Chart 3 reports the long-term rate of $\mathrm{Ml}$ growth (measured by its 12 quarter moving average) and the quarter-to-quarter

\footnotetext{
${ }^{17}$ There is exhaustive literature attesting to the existence of a long lag between money growth and inflation rates. For recent evidence, see Keith M. Carlson, "The Lag From Money to Prices," this Review (October 1980), pp. 3-10; John A. Tatom, "Energy Prices and Short-Run Economic Performance," this Review Ianuary 1981), pp. 3-17; and Dallas S. Batten, "Money Growth Stability and Ioflation: An International Comparison," this Review (October 1981), pp. 7-12.
}

rate of growth of the implicit price deflator for GNP for the United States. In general, the path of inflation follows that of long-run money growth. In fact, after accounting for oil-price shocks, long-run Ml growth explains over 80 percent of the variation in the quarterto-quarter rate of inflation. ${ }^{\text {is }}$

\footnotetext{
${ }^{13}$ See Carlson, "The Lag From Money to Prices." The results of estimating a similar inflation equation over the II/1960 to IV/1982 period are:

$$
\begin{aligned}
& \dot{P}_{\xi}=-0.866+1.091 \stackrel{12}{\Sigma} \dot{\mathrm{M}}_{\mathrm{t}-\mathrm{i}}-1.736 \mathrm{D} 1+0.695 \mathrm{D} 2 \\
& \text { (2.19) } \quad(13.30)+=0 \quad(3.43\} \quad(1.42)
\end{aligned}
$$

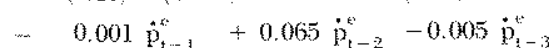

$$
\begin{aligned}
& \text { (0.11) } \mathrm{p}_{\mathrm{t}-\mathrm{1}} \quad(3.96) \quad(0.29) \\
& +\quad 0.041 \dot{p}_{t}^{*} \\
& (2.93)^{\mathrm{t}}
\end{aligned}
$$$$
\overline{\mathrm{R}}^{2}=.83 \quad \mathrm{SF}=1.19 \quad \mathrm{DW}=1.88
$$

where $\dot{P}_{1}$ is the rate of inflation (meastred by the $\mathrm{CNP}$ price deflator) in quarter $t, D l$ and $D 2$ are dummy variables for the control and decontrol phases of the Nixon wage-price control period, $\tilde{p}^{\prime}$ is the growth rate of the relative price of energy and the absolute values of $t$-statistics are in parentheses.
} 


\section{Chort 4}

Deviations of Short-Run Money Growth from Trend 4

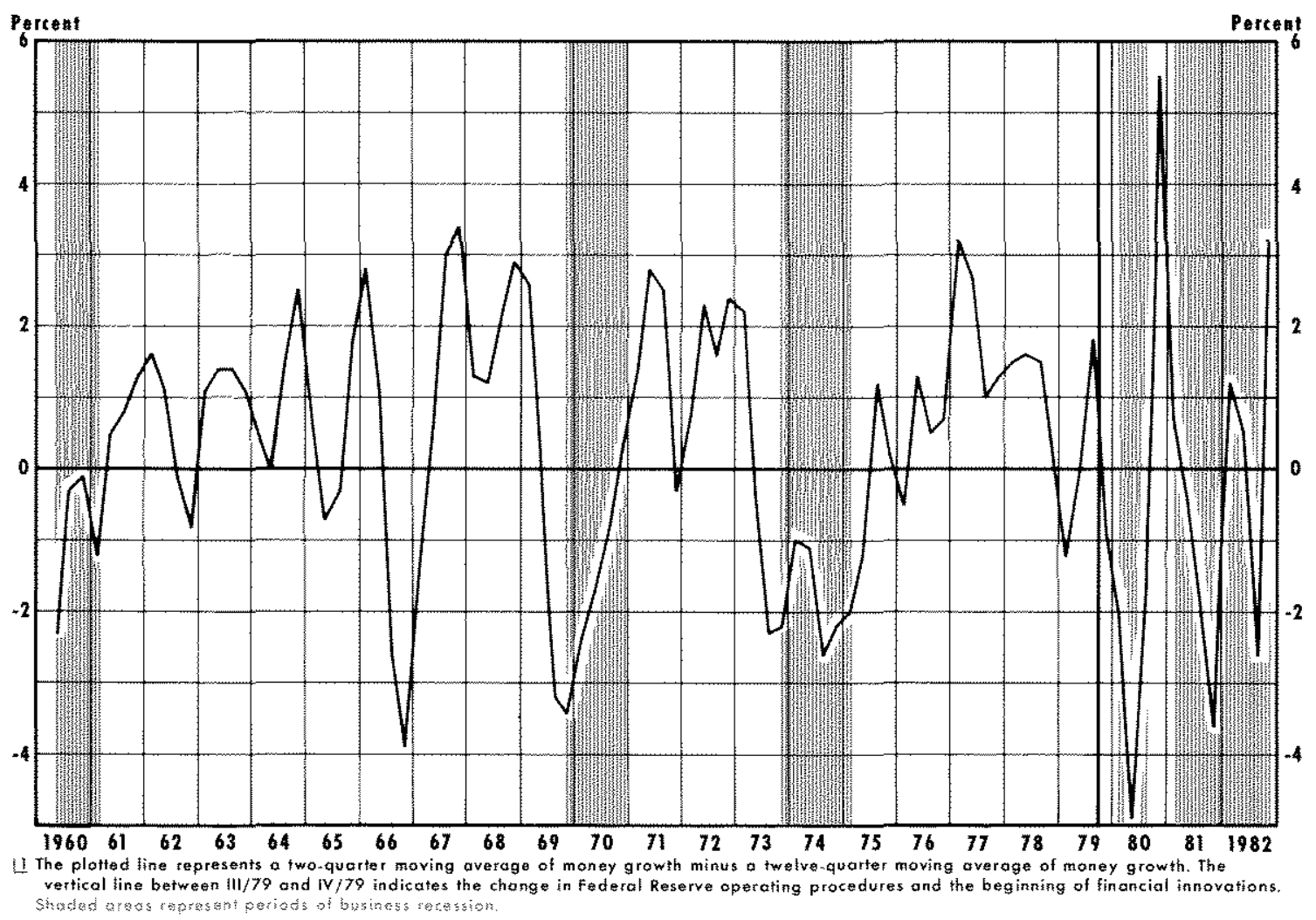

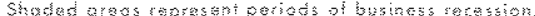

Once again, there appears to be no significant breakdown in this relationship after late 1979: the long-run rate of money growth has declined during the past $3 / 2$ years as has the rate of inflation. Moreover, an econometric investigation indicates that there has been no breakdown in the $M I$-inflation relationship over the past three years. ${ }^{19}$

Proposition 3: Short-run changes in money growth, if sufficiently sharp, produce real output movements. Conceptually, a change in money growth creates a monetary disequilibrium: the quantity of money that individuals desire to hold differs from the quantity that they actually are holding. By altering their rate of spending, they attempt either to increase or to decrease their money holdings to a desired level. Eventually, as discussed previously, this change in the rate

\footnotetext{
${ }^{19} \mathrm{~A}$ more rigorons investigation of a breakdown in the money growth-inflation relationship entails conducting a test similar to that in footnote 15 for the inflation equation cited in footnote 18. The calculated $F$-statistic for this test is 1.53 , well below the critical value of 2.72 at the 5 percent significance level. The hypothesis that the coefficients on MI growth in the inllation equation have changed since III/1979 an be rejected.
}

of aggregate spending will cause a change in the rate of inflation.

In the short run, however, producers cannot tell immediately whether this change in the rate of aggregate demand (spending) is permanent or merely temporary; thus, they respond initially by changing their rate of production. That is, the change in money growth results in a deviation of real economic activity from its "normal" rate. Only when the change in spending (motivated by the monetary disequilibrium) has been identified as permanent will producers change their prices and retum production back to its normal rate. Thus, the impact of a change in the rate of money growth shows up initially and temporarily on. output and employment.

This proposition is demonstrated in chart 4, which reports the deviation of short-run $\mathrm{Ml}$ growth (mea-

\footnotetext{
${ }^{20}$ For a discusston of the microeconomic rationale behind the timing of the effect of changes in money growth on real output (initially) and prices (nltimately), see Cartson, "The Lag From Woney to Prices," pp. 6-8.
} 
sured by its two-quarter moving average) from its longrun trend (measured by its 12-quarter moving aver" age). The shaded areas represent periods defined as recessions by the National Bureat of Economic Research. Every downturn in economic activity in the last two decades has been associated with a substantial slowing in money growth relative to its trend; every substantive slowdown in short-run M1 growth has been associated with an economic downturn. ${ }^{21}$ Although the 1966 episode was not technically labeled a recession, the United States experienced a "growth recession"; real GNP growth fell from about 10 percent to zero following the dramatic dedine in money growth in 1966 .

There appears to be no breakdown in this relationship since late 1979. In fact, this proposition is supported quite strongly by recent events. For example, money growth declined substantially in early 1980 (almost 5 percentage points below its trend); accompanying this decline in $\mathrm{Ml}$ growth, real economic activity declined rapidly and dramatically. By the third quarter of 1980 , money growth had rebounded and the economy began pulling out of a short-lived recession. When short-run money growth declined from $5^{1 / 2}$ percentage points above its trend in IV/1980 to about 4 percentage points below its trend by IV/1981 (an unprecedented drop), however, the economy headed into its second recession in as many years, a recession from which we have only recently begun to recover.

Proposition 4: Monetary authorities can control the rate of money growth. Within the context of monetary policy, the first three monetarist propositions are relatively unimportant unless the growth of money is controllable. The money definition that we have used in this study, Ml, consists of currency and checkable deposits, the two things generally offered and accepted in exchange for goods and services. The monetary authority cannot control MI directly because the checkable deposits that make up a large part of M1 are created by depository institutions. The monetary authority, however, through its open market operations

\footnotetext{
${ }^{21}$ Again, this proposition has been documented extensively. See, for example, Milton Friednan and Anna J. Schwartz, "Money and Business Cycles, Reviow of Economics and Statistics (Supplement: Febraty 1963), pp. 32-78; William Poole, "The Relationship of Monetary Decelerations to Business Cycle Peaks: Another Look at the Evidence,"Journal of Finance (June 1975), pp. 697-712; Dalas S. Batten and R. W. Hafer, "Slort-Run Money Growth Fluctuations and Real Economic Activity: Some Implications for Monetary Targeting," this Review (May 1982), pp. 15-20; and Dallas S. Batten and R. W. Hafer, "Is There a Role for Monetary Targeting?" Review of Business and Economic Research forthooming, 1983). The last two articles cited above demonstrate that similar results are found across countries as well.
}

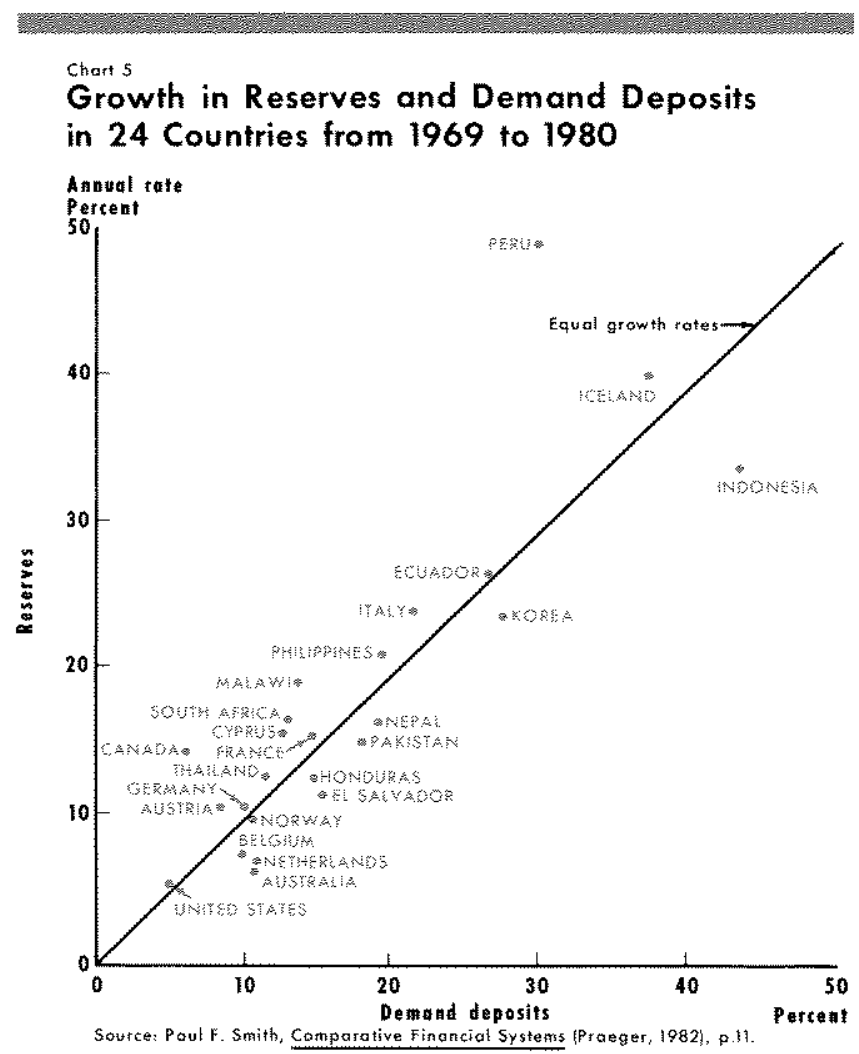

and lending to depository institutions, can control the stock of reserves held by depository institutions upon which these checkable deposits are based. As a result, the monetary authority can control the growth of money supply indirectly by controlling the rate of growth of these reserves. ${ }^{22}$

In the very short run, changing asset preferences of individuals may cause discrepancies between the rate of growth of reserves and that of checkable deposits. Yet, over longer periods of time, these growth rates conform closely across a wide variety of monetary institutions, as exhibited in chart 5 for a large number of countries. This chart illustrates that, over time, reserve growth and demand deposit growth are associated closely. Moreover, because checkable deposits are a large portion of the Ml definition of money, reserve growth is, then, a prerequisite for money growth.

This analysis neglects the role that currency plays in the money supply process. Since currency in the hands of the nonbank public is another potential source of bank reserves, changes in the public's demand for currency also may be the source of monetary expansion

\footnotetext{
${ }^{22}$ See Anatol B. Balbach, "How Controllable is Money Growth?" this Review (April 1981), pp. 312 .
} 


\section{Chart 6}

Growth of $M 1$ and the Adjusted Monetary Base

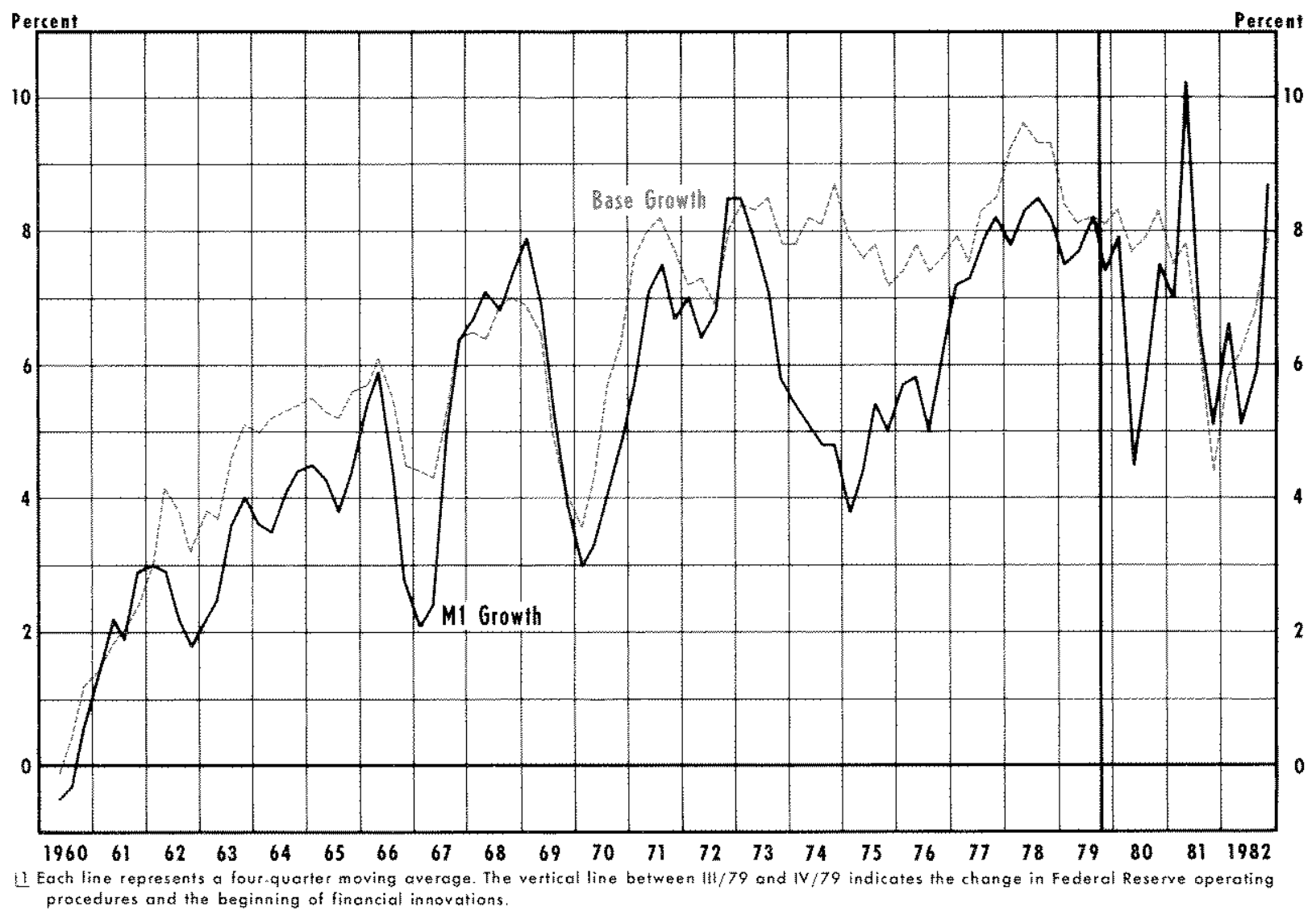

and contraction. Thus, both reserve availability and the amount of currency in the hands of the public must be controlled by the monetary authorities if they desire to control money grow th.

The monetary base is the sum of bank reserves and cumency in circulation. In the United States, it represents a liability of the Federal Reserve. Even though the Federal Reserve does not possess discretionary control over all of the items in its balance sheet, it does have sufficient control to determine the level and growth of the monetary base it desires, even on a weekly basis. ${ }^{2: 3}$

The link between the monetary base and the money supply is the money multiplier. Changes in this multiplier reflect changes in the public's preferences for various financial assets. Since these changes can either intensify or mitigate the impact of Federal Reserve actions, control of the monetary base may still be

${ }^{32}$ See Babach, "How Controllable is Money Growth?" associated with periods of highly variable money growth if changes in the multiplier are highly unpredictable. ${ }^{2 \pm}$ This, however, does not appear to be the case over periods of one year or more.

Chart 6 contains four-quarter moving averages of the rates of growth of the adjusted monetary base and $M I$. Except for the period in the mid-1970s, money growth and base growth have moved together fairly closely. In fact, a 1 percentage-point increase in the rate of base growth leads to approximately a 1 percentage-point increase in money growth. ${ }^{25}$

${ }^{24}$ For a discussion of this point covering the growth of money in 1982, see $R$. W. Hater and Scott $E$. Hein, "The Wayward Money Supply: A Post-Mortem of 1982," this Review (March 1983), pp. $17-25$.

${ }^{25}$ This can be seen more clearly from the following estinated relationship between base growth and MI growh:

$\dot{\mathrm{M}}_{\mathrm{f}}=-0.344+0.921 \dot{\mathrm{B}}_{\mathrm{i}}$ (0.51) $(9.27)$

$\overline{\mathrm{R}}^{2}=.49 \quad \mathrm{SE}=2.29 \quad \mathrm{DW}=1.92$

where $\dot{B}$ is the growth rate of the adjusted monetary base. 
Table 4

\section{Average Absolute Forecast Errors: IV/1979-1V/1982}

\begin{tabular}{|c|c|c|c|}
\hline \multirow[b]{2}{*}{ Mosel } & \multicolumn{3}{|c|}{ Atate gr growth of } \\
\hline & Nominal gur & real $\mathrm{cNP}$ & GNP Deflator \\
\hline 51.40145 & $4.95 \%$ & $3.06 \%$ & $1,49 \%$ \\
\hline Whanon & 462 & 342 & 156 \\
\hline Crase & 492 & 399 & 136 \\
\hline
\end{tabular}

Further, there appears to be no breakdown in this relationship since late 1979. Except for the period of credit controls (II/1980 III/1980), there has been little difference between the rate of base growth and the rate of money growth during the post-IIU/1979 period. ${ }^{26}$

\section{ACLSH OR COMPENAG MODES:

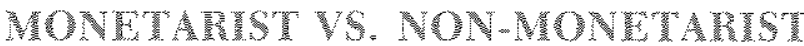

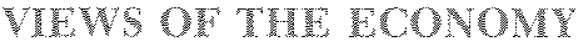

As stated earlier, monetarism can be rejected only if there is an alternative explanation of macroeconomic behavior that has greater explanatory or predictive power. The following experiment was conducted to ascertain whether the primarily non-monetarist economic theories inherent in two of the popular large macroeconomic models could explain economic behavior over the past three years as well as a monetarist model. The St. Louis equation (equation I) and the inflation equation cited in footnote 18 were estimated over the period from II/1960 to IIU/1979. The rates of growth of nominal GNP (total spending), real GNP (real output) and the GNP price deflator then were forecast for the next 13 quarters (that is, from IV/1979 to IV/1982). These forecasts were compared to those of the Wharton and the Chase Econometrics models. The average absolute forecast errors for each of these three models are reported in table 4 ; the cuarterly forecast errors for each variable are shown in charts 7,8 and 9 .

It should be noted, at the outset, that the empirical deck was stacked against the monetarist forecasts; they

\footnotetext{
${ }^{36}$ Again, the stability issue is tested as in footnote 15 for the equation cited in footnote 25 . In this case, the calculated F-statistic is 1.64 , below the critical value of 3.09 at the 5 percent significance level. Consequeratly, the hypothesis that the relationship between base growth and money growth has changed since III/1979 can be rejected.
}

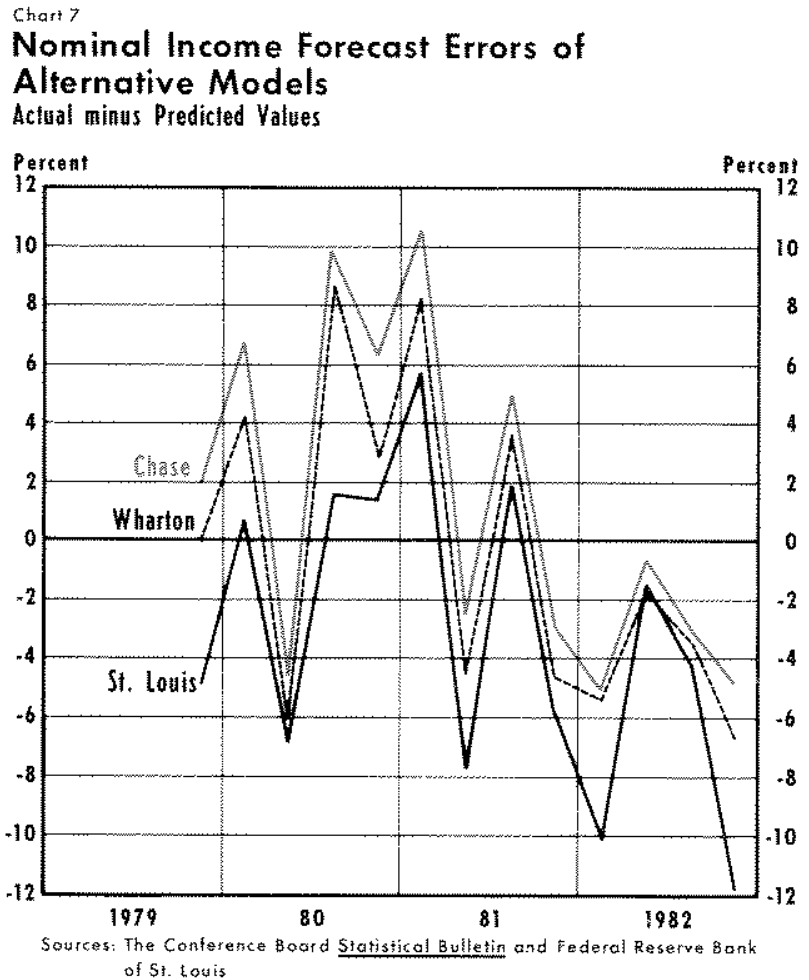

of 5 . Latis

Chorza

Real Income Forecast Errors of

Alternative Models

Actual minus Predicted Yalues

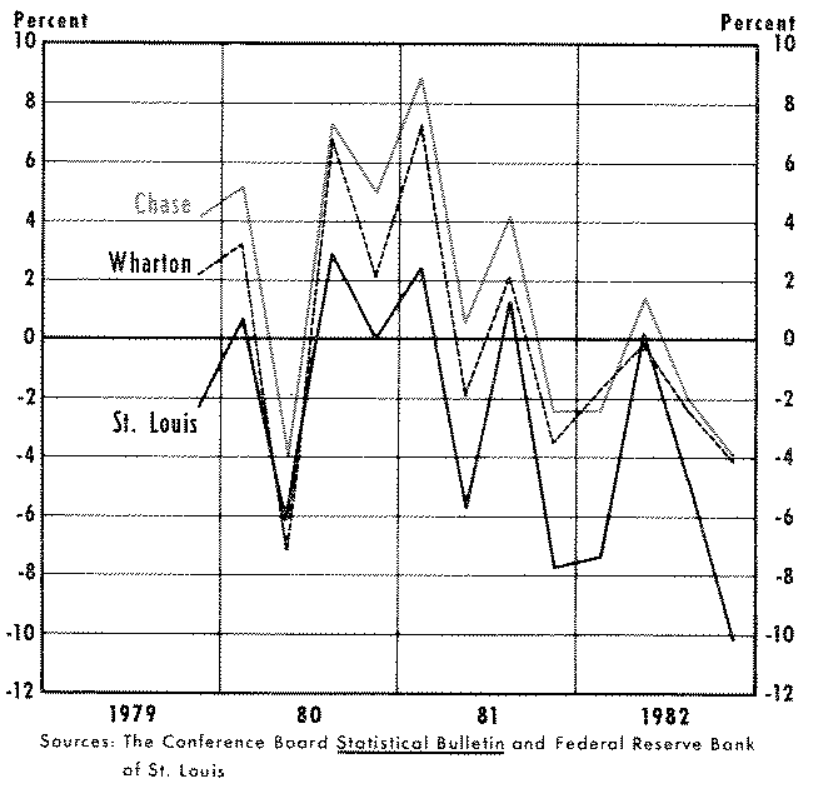

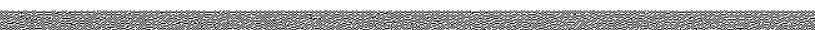




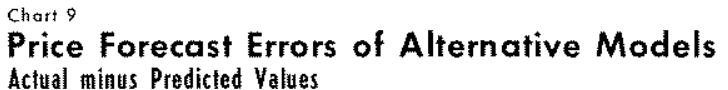

Actual milus Predicted Vallas

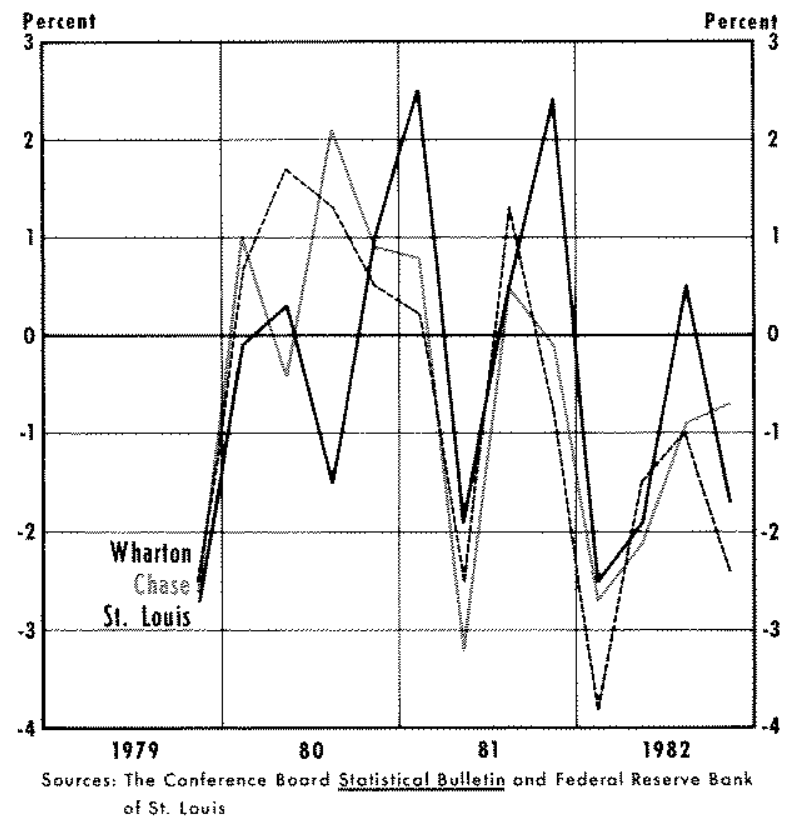

were obtained using coefficients from empirical relationships that were estimated through III/1979 and never updated. The forecasts from both Chase and Wharton were one-quarter-ahead forecasts derived from models that were re-estimated constantly over the period from IV/1979 to IV/1982. ${ }^{27}$ Despite this estimation bias favoring the non-monetarist models, there is virtually no difference in the comparative short-run forecasts for recent years between the presumably outdated monetarist model and the updated non-monetarist ones. For example, while the average annual absolute forecast errors for nominal GNP using the St. Louis model was 4.95 percent, the Chase result was virtually identical, and Wharton's was nearly as large. From the results in table 4 , it is clear that neither of the two alternative models has outperformed this

\footnotetext{
${ }^{27}$ This estimation bias was introduced to compensate for the fact that actual values of the right hand-side variables were used to derive the St. Louis forecasts, while Chase and Whareon did not know these values when they made their forecasts. This type of comparison obvionsly is not the ideal one; it is, however, the best that can be accomplished without aceess to the estimated parameters of the Chase and Wharton models. For simlar comparisons of these models' long-run properties, see Keith M. Carkon and Scott E. Hein, "Four Econometric Models and Monetary Policy: The Longer-Run View, "this Review (Jantary 1983), pp. 13-24.
}

version of a monetarist model over the past three years. ${ }^{28}$

Moreover, the information in charts 7,8 and 9 reveals that the relative performance of the St. Louis forecasts generally has remained constant throughout the forecast period. That is, the $S t$. Louis forecasts did not collapse, relative to those of Chase and Wharton, as financial innovation continued throughout the forecast period. If monetarism has died, it surely was not killed off by the superior performance of whatever theoretical relationships underlie these major non-monetarist economic models.

\section{SUMNAWINAD CONCUUSONS}

Monetarism can be viewed in two ways. It is a scientific theory that stresses the importance of focusing on the level or growth of money in order to understand the behavior of such key macroeconomic variables as prices, real output and spending. As a scientific theory, it also stresses the importance of focusing on the behavior of the monetary authority in order to understand how and why money grows the way it does. Monetarism also can be viewed as a diverse collection of normative propositions about how fast money should grow or what the proper monetary policy should be. While disputes over normative propositions are generally insolvable, the validity of scientific propositions can be examined.

This paper has assessed the claim that monetarism, in the scientific sense, has failed, by testing four key monetarist propositions to see whether they can explain economic events over the past three years. Contrary to recent rumors of the death of monetarism, we found that the four propositions tested were as valid and useful over the past three years as they had been over the prior 20 years. Moreover, when compared with the predictive behavior of two well-known nonmonetarist econometric models, we found that a simple monetarist analysis worked equally well in explaining the economic patterns of spending, output and prices over the past three years. Rumors of the death of monetarism have, indeed, been exaggerated.

\footnotetext{
${ }^{28}$ Similar results are obtained when root mean square errors (RMSE) are compared for the three models. This method of summarizing forecast errors gives nore weight bo large erors than does the average (mean) absolute error.

\begin{tabular}{lccc}
\multicolumn{4}{c}{$\begin{array}{c}\text { RMSE for forecasts of the } \\
\text { groweh rate of }\end{array}$} \\
\cline { 2 - 4 } Model & Nominal GNP & Real GNP & GNP Deflator \\
\hline St. Lonis & $5.99 \%$ & $5.03 \%$ & $1.74 \%$ \\
Whatton & 5.18 & 4.06 & 1.83 \\
Chase & 5.68 & $=3.54$ & 1.69
\end{tabular}
}

